\title{
EFFECT OF DIETARY ENERGY SOURCES ON RUMEN KINETICS, FEED UTILIZATION, WEIGHT GAIN, AND PHYSICAL - CHEMICAL CHARACTERISTICS OF MEAT IN SHEEP
}

\section{S. M. Salem}

Animal Production Department, Faculty of Agriculture, Cairo University, Giza, Egypt

\section{SUMMARY}

The effect of different sources of energy (protected fat and carbolydrate) on rumen function, nutrient digestibility, weight gain and physical-chemical characteristics of meat were studied on twenty Lybian adult rams in averaged age 1.5 year. Animals were divided into two homogenous groups. Rams of the first group (served as control) fed barley grains, barley straw , alfa alfa hay (T1) while rams of the second group fed barley grains, barley straw, alfa alfo hay and calcium salt of corn oil fatty acids (T2). The two diets were formulated to contain the same energy and protein content. Four rams from each group were slaughtered after 120 days from the start of experiment.

Feeding on diet 2 (T2) had no significant effect on ruminal volatile fatty acids, $\mathrm{pH}$, buffering capacity and ammonia nitrogen concentration. Meanwhile digestibilities of organic matter (OM), crud protein (CP), crud fiber (CF), and ether extract (EE) and nitrogen free extract (NFE) were higher $(\mathrm{P}<0.05)$ in $\mathrm{T} 2$ compared to $\mathrm{T} 1$. The rams in $\mathrm{T} 2$ showed higher $(\mathrm{P}<0.05)$ growth rate correspondingly better feed efficiency, as will as a ligher dressing percentage $(\mathrm{P}<0.05)$ than $\mathrm{Tl}(52.15 \%$ vs. $44.96 \%)$. Physical characteristics of meat ( $\mathrm{pH}$ values and cooking loss \%) were similar in the two groups. The significant differences $(\mathrm{P}<0.05)$ in chemical composition of longissimus dorsi muscle were found in fat and ash percentages only in $\mathrm{T} 2$.

Keywords: Sheep, calcium salt, food utilization, carcass characteristics

\section{INTRODUCTION}

Sheep in many countries are considered as the main favorable source of red meat. They are characterized by their ability to convert low quality feed into proteins of high biological value and digestibility, but even though this is true, many management systems do not guarantee an adequate growth rate (Penedo et al., 1988).

Supplementing diets of ruminants with fat permits' greater energy consumption especially when dry matter intake is limited by rumen capacity targting to achieve the required energy intake. (Kronfeld, 1976 and Brumby et al., 1978).

Addition of vegetable oil in feed rations can modify the amino acid profile of meat and depot fat (Rumsey et al., 1972; Westerling and Hedrick, 1979; Busloom et al., 1981; Larick and Turner, 1989; Lough et al., 1992; Alaroni et al., 1995 and Preziuso et al., 1999).However, more than 5\% fat in diets has found to reduce feed intake and growth performance (Haaland et al., 1981)

To prevent unfavorable effect of fat intake on rumen fermentation recent $\mathrm{Ca}$ - soaps of long chain fatty acids was utilized. These protected fats are insoluble at normal rumen $\mathrm{pH}$ and are thus inert towards fermentative digestion (Chalupa et al., 1986). In the abomasum they are converted by acid to free fatty acids and calcium ions. The fatty acids are then absorbed efficiently in small intestine (Schneider et al., 1988).

In desert or new reclaimed lands, utilization of fat in sheep diets may be one of the alternatives to cover energy requirements and inhance growth rate.

Accordingly, the objectives of this study were to evaluate the use of calcium salts of long chain fatty acids as a source of energy, on rumen function parameters, food digestibility, growth rate, dressing percentages and some physical and chemical characteristics of meat.

\section{MATERIALS AND METHODS}

Twenty adult rams of local breeds of Lybia had an average $35 \pm 3.14 \mathrm{~kg}$ weight and 18 months age were randomly divided into two equal groups $(n=10)$ fed isocaloric and iso protien rations according to 
NRC (1988) and were assigned in digestion cages. The first group (T1) served as control and was fed ration containing $450 \mathrm{~g}$ barley grains, $125 \mathrm{~g}$ alfa alfa hay and $200 \mathrm{~g}$ barley straw. The second group (T2) was fed $300 \mathrm{~g}$ barley grains, $215 \mathrm{~g}$ alfa alfa hay, $200 \mathrm{~g}$ barley straw and $70 \mathrm{~g}$ calcium salt. The procedure for the preparation of calcium salt is as follow; $100 \mathrm{~g}$ of commercial corn oil, was added $13.6 \mathrm{~g}$ of calcium hydroxide and $150 \mathrm{~g}$ of water and stirred. Fifty $\mathrm{mg}$ of $0.5 \%$ lipase derived from Psudomonas Fluorscens (Amano Pharmaceutical Co., Ltd.) was added to the mixture and stirred to gel. After standing for $3-5$ hrs, the gel separated into liquid and solid. The calcium salt obtained from the solids was air dried at room temperature for $7-8 \mathrm{hrs}$ and crashed. The energy value and calcium soap $7.8 \mathrm{cal} / \mathrm{g}$ and $7 \%$ respectively. Rations were offered once daily at $08.00 \mathrm{~h}$, and fresh water was made available all day times. Nutritive values of ration ingredients are shown in Table 1 . Chemical compositions of feces were determined according to A.O.A.C. (1990).

Table 1. Nutritive values of experimental feed

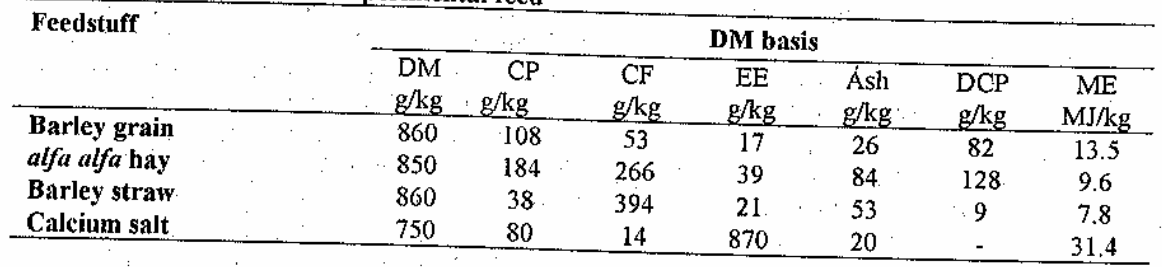

After termination of the experiment, animals were kept individually in metabolism crates for 35 days, the last 7 days were considered as a collection period for digestibility assessment. Rumen samples were collected by. stomach tube; within two successive days following the digestibility trail before feeding and at 4and 8 hrs. post feeding.

Concentration of ruminal ammonia nitrogen was determined according to Convway (I963) and of total volatile fatty acids according to Kroman et at. (1967). Rumen fluid $\mathrm{pH}$ was determined inmediately using digital $\mathrm{pH}$ meter and buffering capacity was determined according to Nicholson $e$ al. (1980)

At the end of the experiment (120days), four rams from each group were slaughtered. Weight of empty hot carcasses was recorded and the left side of each carcass was chilled for 24 hr at $5^{\circ} \mathrm{C}$. The longissimus clorsi muscle of the 9,10 and 11 th ribs was separated for meat analysis. According to A.O.A.C. (1990), moisture, ash and fat percentages were determined, while protein percentage was calculated by difference Johnson et al. (1986). The $\mathrm{pH}$ value was determined after $24 \mathrm{hr}$ of slaughter using Gallen-kamp pH meter to the nearest 0.01 . Meat samples were cut into cubes of about $30 \mathrm{~g}$ each $\left(W_{1}\right)$ and were boiled in water for 45 minute. Samples were put in a leat tolerant plastic bags then weighted $\left(\mathrm{W}_{2}\right)$. Cooking loss $(\mathrm{CL})$ was calculated as follows.

$\mathrm{CL} \%=\left\{\left(\mathrm{W}_{1}-\mathrm{W}_{2}\right) / \mathrm{W}_{1}\right\} * 100$ Difference between the two treatment means of studied traits was tested using student $-\mathrm{t}$ test
according to Steel and Torrie (1960).

\section{RESULTS AND DISCUSSION}

\section{Rumen liquor parameters}

No significant difference between ruminal volatile fatty acids (VFAs) concentrations, the two studied groups was observed (Table2). This agrees with that result of Jenkins and Jenny (1989) who stated that total VFA concentration did not significantly clange when slecp fed calcium salt of fatiy
acids.

The insignificant reduction in numen liquor $\mathrm{pH}$ in $\mathrm{T} 2$. Tlicse data agree with those described by Palmquist et al. (1986) and Salem (1996) who observed lower pH values in rumen liquor of rams fed greater production salt of fatty acids. They suggested that adding calcium salt might cause greater production of fermentation acids. Also, as they reported that rumen $\mathrm{pH}$ and total VFA $0.01)$. These results indicate time after feeding were highly correlated with each others $(r=0.75, p<$ $0.01)$. These results indicated that protected fat has no determinable effect on rumen fermentation as ported previously by Jenkins and Jenny (1989).

The content of $\mathrm{NH}_{3}-\mathrm{N}$ was in the range of normal values, and there was no detectable differences between the two groups were detected. These results are in agreenent with Harrison et al. (1995) who 
reported that, addition of supplemental fall had no significant effect on ruminal concentration of VFA. $\mathrm{NH}_{3}-\mathrm{N}$ or in situ digestibility of fiber.

Table 2. Rumen parameters of lybian local sheep fed calcium salt (T2) and control (T1)

\begin{tabular}{|c|c|c|c|}
\hline Item & T1 & T2 & $\mathbf{P}$ \\
\hline \multicolumn{4}{|c|}{ Total Volatile Fatty Acids m.equiv. /dl. Rumen Liquor } \\
\hline Before feeding & 24.4 & 23.9 & $\mathrm{Ns}$ \\
\hline $4 \mathrm{hr}$. after feeding & 29.9 & 31.6 & Ns \\
\hline $8 \mathrm{hr}$. after feeding & 29.3 & 30.1 & Ns \\
\hline $\begin{array}{l}\text { General mean } \\
\text { rumen liquor pH }\end{array}$ & 27.9 & 28.3 & Ns \\
\hline Before feeding & 6.68 & 6.45 & Ns \\
\hline $4 \mathrm{hr}$. after feeding & 6.01 & 5.82 & Ns \\
\hline $8 \mathrm{hr}$. after feeding & 5.89 & 5.67 & Ns \\
\hline General mean & 6.12 & 6.06 & Ns \\
\hline \multicolumn{4}{|c|}{ Buffering Capacity ( $\mathrm{ml} \mathrm{Hel} 0.1 \mathrm{~N} / \mathrm{dl}$ rumen liquor) } \\
\hline Before feeding & 79.9 & 82.0 & Ns \\
\hline $4 \mathrm{hr}$. after feeding & 76.75 & 80.6 & Ns \\
\hline $8 \mathrm{hr}$. after feeding & 80.25 & 82.1 & Ns \\
\hline General mean & 79.7 & 80.9 & Ns \\
\hline \multicolumn{4}{|c|}{ Ammonia nitrogen $\mathrm{ml} / \mathrm{dl}$} \\
\hline Before feeding & 9.5 & 11.0 & Ns \\
\hline 4 hr. after feeding & 10.6 & 11.5 & Ns \\
\hline $8 \mathrm{hr}$. after feeding & 10.0 & 10.8 & Ns \\
\hline General mean & 10.03 & 11.1 & Ns \\
\hline
\end{tabular}

ns $=$ not significant at $p<0.05$

Digestibilities and nutritive values

The obtained digestibility coefficients of dietary nutrients and the nutritive values were better in $\mathrm{T} 2$ than Tl (Table 3). Digestibilities of organic matter (OM), crude protein (CP), crude fiber (CF), ether extract (EE) and nitrogen free extract (NFE) were increased in supplemented protected fat rations compared will the control ration.

Table 3. Digestion cocfficients and nutritive values of experimental rations

\begin{tabular}{lccc} 
Item & T1 & T2 & P \\
\hline Digestibility \% & & & $*$ \\
OM & 62.1 & 75.0 & $*$ \\
CP & 60.3 & 79.9 & $*$ \\
CF & 75.1 & 85.5 & $*$ \\
EE & 30.6 & 45.3 & $*$ \\
NFE & 80.4 & 91.6 & $*$ \\
Nutritive value & & & \\
TDN & 62.6 & 70.7 & $*$ \\
\hline p $<0.05$ & &
\end{tabular}

These results coincide with those of (El-Bedawy ef al., 1995 and Salem, 1996) who stated that feeding calcium salt of fatty acids increased digestibility of EE, NFE, and CP. due to the high digestibility of the triglycerides which are most plentiful in calcium salt of fatty acids. Calcium salt of fatty acids as a source of protected fat had no effects on rumen microorganisıns activities while it provide the animal by dense source of energy which improved the digestion of uttrient components (Paqlimquist, 1989).

The nutritive value (TDN) of fat supplemented diet with calcium salt of fatty acids was higher than that of unsuplemented diet due to their high contents of ether extract and high digestibility values of $\mathrm{CP}, \mathrm{CF}$, and NFE in calcium salt rations than in control diet.

The growth performance of rams of $\mathrm{T} 1$ and $\mathrm{T} 2$ is presented in Table 4 . However dry maller (DM) intake was approximately similar, the feed efficiency and average daily gain were better $(P<0.05)$ in T2 thanT1. These results are in accordance with those of Haaland et al. (1981) who reported that, live 
animal performance of steers fed medium fat diet had superior values $(p<0.05)$ compared to that of the low fat fed steers, as evaluated by feed intake, live weight gain and feed efficiency.

Table 4. Performance and feed intake for rams fed control and calcium salt diets for 120 days (means + SE)

\begin{tabular}{lccc}
\hline Item & T1 & T2 & P \\
\hline No. rams & 5 & 5 & Ns \\
Avg. Initial wt, Kg. & $35.4 \pm 2$ & $34.5 \pm 1.5$ & Ns \\
Avg. final wt, kg. & $45.6 \pm 3.8$ & $48.9 \pm 3.6$ & $*$ \\
Avg. daily gain, g & $90 \pm 8$ & $120 \pm 10$ & $*$ \\
Daily dry matter intake, g. & $688 \pm 90.5$ & $707 \pm 44$ & Ns \\
Feed efficiency, gain/DM intake. & 0.13 & 0.17 & $*$ \\
\hline
\end{tabular}
$\mathrm{ns}=$ not significant $*=p<0.05$

Also, Zinn (1989) showed linear increases in daily gain $(\mathrm{p}<0.01)$ with increasing level of fat in the diet of steers $(0,4,8 \%$ fat). In the same trend Tamming et al. (1983), Murphy et al. (1987), Zinn (1988) and Palmquist (1989) reported that, inclusion of protected fat in ruminant rations encourage microbial protein production and daily gain of the treated animals. On contrast to the present study Bendary et al. (1994) reported that the inclusion of different levels of fat in rations of sheep did not affect daily gain.

\section{Carcass characteristics}

Rams of T2 had heavier carcasses and better dressing percentage $(P<0.05)$ than of T1 (Table 5), which is in agreement with those of Borroto et al.(1994) who concluded that carcasses weight and dressing percentage were affected by energy sources.

Table 5. Carcass characteristics of rams fed rations contained protected fat

\begin{tabular}{lccc}
\hline Item & T1 & T2 & P \\
\hline Hot carcass & & 4 & \\
No. rams & 4 & 52.15 & $*$ \\
Dressing percentage & 44.96 & $25.5 \pm 3.1$ & $*$ \\
Weight ,kg & $20.5 \pm 2.5$ & $5.85 \pm 0.08$ & ns \\
pH & $5.63 \pm 0.1$ & $45.44 \pm 3.4$ & ns \\
Cooking loss \% & $48.2 \pm 2.6$ & $*=\mathrm{p}<0.05$ &
\end{tabular}

Most physical properties of meat are related to $\mathrm{pH}$ values (Salem et al. 1982). The $\mathrm{pH}$ of the meat did not differ significantly between the groups (5.85 in diet with calcium salt verses 5.63 in control group) between diets, which indicates that the two diets had no effect on these characteristics. This result agree with those reported by Salen et al. (1982) and El-Kholy (1999) in Friesian and buffaloes meat.

Table 6. Chemical composition of tongissimus dorsi muscle of rams fed ration containing protected fat

\begin{tabular}{llll}
\multicolumn{1}{l}{ Prom } & T1 & T2 & P \\
\hline Moisture \% & $70.2 \pm 5.9$ & $69.2 \pm 9.1$ & ns \\
Fat \% & $10.0 \pm 2.1$ & $11.7 \pm 1.9$ & $*$ \\
Protein \% & $18.7 \pm 4.9$ & $17.6 \pm 6.1$ & $\vdots$ \\
Ash \% & $1.06+0.1$ & $1.5 \pm 0.09$ & ns \\
\hline Values shown are mean + SE & ns $=$ not significant & $*$
\end{tabular}

The differences in cooking loss percentage between treated groups were not significant $(48.2,45.4$ in control diet and calcium salt diet, respectively). These results are in harmony with those of Bendary et al. (1994).

Chemical composition of meat from the lumber region (longissimus dorsi), was not affected by the dietary fat content, except fat and ash. Sarti et al. (1993) reported lower percentage of ether extract than the present study (average $5.07 \%$ versus $11.658 \%$ respectively), and consequently higher moisture and protein content. 
These results are du to the higher content of fat and calcium in T2 than those in the T1. Results of this experiment indicate that a higher utilizable energy value is warranted for the calcium salt ration than control diets. In relation to this point, Haalarid et al. (1981) reported that diet containing protected tallow had higher utilizable energy value is warranted for the calcium salt ration than control diet.

In conclusion, the concentrate portion of the ration could be replaced partially by calcium salts of fatty acids without adverse effect on rumen fermentation. The productive performance of fattening rams could be improved as reflected on carcass properties.

\section{REFERENCES}

Aharoni Y., E.Nachtomi, P. Holstein, A. Brosh, Z. Holzer, Z. Nitsan, 1995. Dietary effects on fat deposition and fatty acid profile in muscles and fat depots of Friesian Bull Calves. J. Anim. Sci.,73: 2717-2729.

A.O.A.C., 1990. Official Methods of Analysis (15th Ed.) Association of Official Analytical Chemists, Arlington, U.S.A.

Brumby P.E., J.E. Storry; J.A. Bines and R.J. Fulford, 1978. Utilization of energy for maintenance and production in dairy cows given protected tallow during early lactation. J. Agric. Sci., (Cambridge) 91: 151-159.

Busloom, I.R., G. Miller, R.A Field, I.D. Crouse, M.L Riley, G.E Nelms, C.L. Ferrell, 1981. Characteristics of fat from heavy ram and wether lambs. J. Anim. Sci., 52: 83-92.

Chalupa W., B.V.A. El-Ser, D.S. Kronfield, D.Sklan and D. Palmqusit, 1986. Ruminal fermentation in vivo as influenced by long chain fatty acids. J. Dairy Sci., 67:1439-1508.

Church D.C., 1981. Digestive Physiology and Nutrition of Ruminamt. Chapter 16: pp in Vol. 1. Digestive Physiology 2 nd Ed., 299.D.C.Church, USA.

Conway, E.J., 1963. Microdiffusion Analysis and volumetric error, pp.90-101. London: Crosby Lockwood \& son.

El-Bedawy,T.M.,1995. Preparation of sunflower oil calcium soap as protected fat and its use in ruminant nutrition. J. Agric. Mansoura Univ., 20 (1): 231-239.

El-Kholy A.F., M.A.I.Salem, M.A.M. Ibrahim and A. S. Sami. ,1999. Meat quality of Egyptian Buffalo and Friesian males implanted with anabolic agents. Egypt.. J. Anim. Prod. 36: 1-7.

Haaland, G.L., J.K. Motsushima, D.E. Johson and G.M.Ward, 1981. Effect of repot corn by protected tallow in a cattle-finishing diet on animal performance and composition. J. Anim. Sci., 52: 696-702

Harrison J., H ,R.L. Kincaid., J.P.MacNamara, S. Waltener, K. A. Loney, R.E.Riley and Cronrath, 1995. Effect of whole cottonseed and calcium salts of long chain fatty acids on performance of lactating dairy cows. J. Dairy Sci.,78:181-193.

Jenkins, T. C. and D.H. Jenny, 1989. Effect of hydrogenated fat on feed intake, nutrient digestion and lactation performance of dairy cows. J.Dairy Sci., 72: 2316-2321.

Johnson, R.C., D.H. Gee, W.J. Castello and C.W. Calson, 1986. Effect of anabolic implants and breed group on carcass trails and palatability characteristics of bullock beef. J. Anim. Sci., 62: 399-402.

Kroman, R. P., J. H. Meyer, and W.J.Stielu, 1967. Steam distillation of volatile fatty acids in rumen ingesta. J. Dairy Sci., 50:73-81.

Kronfeld D.S.; 1976. The potential importance of the proportions of glucogenic. Lipogenic and aminogenic nutrients in regard to the health and productivity of dairy cows. Advances in Animal Nutrition and Physiology, 7: 7-15.

Larick, D.K., Turner, B. E.,1989. Influence of finishing diet on the phospholipid composition and fatty acid profile of individual phospholipids in Ican muscle of beef cattle. J. Anim. Sci., 67:2282-2293,

Lough, D.S., M.B. Solomon, T.S. Rumsey, T.H.Elsser, L.L.Slyter, S. Kaht, , G.P. Lynch, 1992. Effect of dietary cancla seed and soy lecithin in high-forage diets on cholesterol content and fatty acid composition of carcass tissues of growing ram lambs. J. Anim. Sci., 78:1153-1158.

Moron-Fuenmayor O.E. and T. Clavero, 1999. The effect of feeding system on carcass characteristics, non-carcass component and retail cut percentages of lambs. Small Ruminant Resenrch 34: 57-64.

Nicholson, J.W.G., R.E McQueen and P.L Burgess, 1980. Effect of cold digestibility of chopped or pelted hay by sheep. Can.J.Anim.Sci. ,60: 57-63.

NRC (National Research Council), 1988. Nutrient Requirements of Sheep. 6th Rev. ed. Nat. Acad. Sci. Washington D.C.

Palmquist, D.L., T.C Jenkins and A.E.J.R.Joyer, 1986. Effect of dietary fat calcium source on insoluble soap formation in the rumen. J. Dairy Sci., 69: 1020- 1029. 
Penedo, T. A., N.V.Cisneros, , O Sosa,., 1988. Ceba ovina abase de un pienșo eriollo sin cereales y alto comintenido de cachaza desh idratada mas cnsilaje de peseado ACPA 2,52-56.(cited by MoronFuenmayor and Clayero., 1999)

Preziuso,G., C.Russo,L.Casarosa, G. Campodoni, S, Piloni, and D. Cianci, 1999. Effect of diet energy source on weigh gain and carcass characteristics of lambs. Small Ruminant Research, 33: 9-15,

Rumsey T.S., R.R Olten,., K. D.Bouard, , Priode, 1972 . Influence of widely diverse finishing regimes and breeding on depot fat composition in beef cattle. J. Anim. Sci, 32:1969-1072.

Russo, C., G. Preziuso, L.Casarosa, G. Campodonib and D. Cianci, 1999. Effect of diet energy source on the chemical-physical claracteristics of meat and depot fat of lambs carcasses. Small Ruminant Research 33: 77-85.

Salem, M.A.I.; A.Darwish, G.A.Abd El-Hafis and M. Nasrat, 1982. Growth and meat quality of Friesian and buffalo calves fed on different planes of nutrition II. The quality of lean meat. Egyptian. J.Anim.Prod, 22: 83-89.

Salem M. S., 1996. Lipids and fatty acids metabolism in ruminants. Ph.D. Thesis. Animal Production Department, Fac. of Agric., Cairo. Univ.

Schneider, P., D, Sklan, W. Chalupa and D.S Kronfeld,1988. Feeding calcium salts of fatty acids to lactating Cows. J. Dairy Sci.,71, 2143 - 2150.

Steel R.G.D. and J. H. Torrie, 1960. Principles and procedures of statistics. Mc Graw- Hill-Book Company inc. New York.

Tamming S., A.M. Van Vuuren, C. J.Van der Koelen, H.M.Khattab and L.G.Van Gills, 1983. Further studies on the effect of fat supplementation of concentrates fed to lactating dairy cows. 3 . Effect on rumen fermentation and site of digestion of dietary components. Neth. J. Agric. $31: 249-258$.

Westerling D.B. and H.B Hedrick, 1979. Fatty acid composition of bovine lipids affected by diet, sex and anatomical location and relationship to sensory characteristics. J. Anim. Sci., 48: 1343-1348.

Zinn, R.A., 1989 . Influence of level and source of dielary fat on its comparative feeding value in finishing diets for steers: Feedlot cattle growth and performance. J. Animal. Sci, 67: 1029 - 1037. 